Relations industrielles

Industrial Relations

\title{
Cheney, George, Values at Work: Employee Participation Meets Market Pressures at Mondragon
}

\section{George Strauss}

Volume 55, numéro 3, 2000

URI : https://id.erudit.org/iderudit/051335ar

DOI : https://doi.org/10.7202/051335ar

Aller au sommaire du numéro

Éditeur(s)

Département des relations industrielles de l'Université Laval

ISSN

0034-379X (imprimé)

1703-8138 (numérique)

Découvrir la revue

Citer ce compte rendu

Strauss, G. (2000). Compte rendu de [Cheney, George, Values at Work: Employee Participation Meets Market Pressures at Mondragon]. Relations industrielles /

Industrial Relations, 55(3), 537-539. https://doi.org/10.7202/051335ar

Tous droits réservés @ C Département des relations industrielles de l'Universite Laval, 2000
Ce document est protégé par la loi sur le droit d'auteur. L’utilisation des services d'Érudit (y compris la reproduction) est assujettie à sa politique d'utilisation que vous pouvez consulter en ligne.

https://apropos.erudit.org/fr/usagers/politique-dutilisation/ 
organization collide, setting out an interesting and important research agenda for the future.

The final two chapters in the volume look at dispute resolution in the public sector and in construction. The former, by Jill Kriesky, highlights a general lack of research assessing grievance procedures in the public sector and, in particular, the way in which dispute procedures under collective agreements interact with an array of civil service, merit, and other adjudicative mechanisms. The same issue arises in Canada, and as in the United States, has also received insufficient attention. The final chapter in the volume, by Heather Grob, looks at the construction industry and is fascinating on two accounts. First, there is a long tradition of dispute procedures that go well beyond union-management disputes, such as inter-union jurisdictional tribunals. Second, and most interesting, the construction industry's seemingly arcane rules are not seen as a dinosaur of the past but as a harbinger of the future. The employee side is characterized by a contingent workforce, occupational unions that control entry and training, and industry based (rather than employer based) pensions and benefits. On the employer side, competitive bidding, outsourcing, constantly changing technology, many small employers, and constant entrants to the market were a fact of life well before the high tech sector was invented. Professor Grob makes a persuasive case for looking to the construction industry as a model of future workplace relationships.

In short, this is a book that must be added to the collection of all industrial relations scholars, even those whose main interests lie outside dispute resolution. For Canadian academics, the debate over nonunion arbitration is fascinating and essential reading. Indeed, there is some anecdotal evidence of the importing of such systems into the Canadian operations of American companies.

\section{Allen Ponak University of Calgary}

\section{Values at Work: Employee Participation Meets Market Pressures at Mondragon \\ by George ChEney, Ithaca and London: ILR Press, 1999, 189 p., ISBN 0- 8014-3325-8.}

Mondragon has been widely viewed as a model of workers' participation: a worker owned and democratically run organization which is also highly successful. Founded by a Catholic priest in the Basque country of Spain during the 1940s and 1950s, this closely linked set of producers' cooperatives has grown to include 150 firms, 42,000 employees and over $\$ 7$ billion in sales.

There have been numerous studies seeking to explain Mondragon's success. The present volume asks another question: has this success come at the cost of Mondragon's soul? Has it maintained its social values (democracy, equality, and solidarity) or has it become more concerned with competitiveness, productivity and pleasing the customer? The author, a student of communications, is concerned with how patterns of discourse reveal fundamental aspects of organizational life. His research involved over 300 interviews and over six months of observation spread over a seven-year period, concentrating on three affiliated coops.

Considerable evidence is presented as to how and why Mondragon's values have degenerated. Historically, "solidarity" - communal obligation and a sense of equality - was a fundamental Basque value, and this was reinforced by the geographical isolation of the separate valleys into which the Basque territory is divided. Mondragon was a 
by-product of Basque solidarity against Franco. But after Franco's death, Spain became more democratic and Mondragon less of a political statement. Transportation improved. Mondragon expanded beyond its mountain heartland. With improving standards of living, individualistic values (getting ahead) began replacing communal traditions. Structural change helped further reduce commitment. Originally most coops covered but a small area, often a single valley, and so communal loyalty reinforced work place ties. On the other hand, a single coop might produce several products, some competing with sister coops elsewhere. In the face of market pressures, this was changed. The coop structure was reorganized on the basis of product lines rather than geography. Thus the community-organization link was weakened. Meanwhile the organization became more bureaucratic.

Over time, Mondragon has taken on some of the characteristics of a traditional capitalistic firm. Once Spain joined the European Union market, competition heated up and pressures on workers to increase productivity intensified. Worker dissatisfaction led to a short strike. Strikers were dismissed, but then after much organizational soulsearching, reinstated. Several individual coops quit Mondragon to form a federation of their own. The maximum pay allowed top management, once not more than 4.4 times that of the lowest paid workers, was raised in steps. Temporary workers were hired without the benefit of coop membership. Much recent expansion has involved taking over existing firms which lack Mondragon's cooperative history.

On the other hand, Mondragon's structure remains essentially unchanged. In each coop an elected governing council appoints the general manager and is concerned with workers' interests as owners, while an elected social council represents their interests as workers and serves as a quasi union. In addition, there is an annual general assembly which workers are required to attend. Representatives of each of the constituent coops form the Cooperative Congress. Yet many social councils are relatively inactive and general assemblies tend to be rather formal with the general manager reading a report followed at times by "position papers" read by critics. At least criticism continues. Further, there is an organized opposition group (KT) which serves as a quasi-union.

Participation remains high, but it is of a different kind. Earlier participation involved organizational governance but work itself was organized in a traditional Tayloristic fashion. Today major organizational decisions are made with less individual worker input; much greater emphasis is given to shop-floor participation including forms of on-line and off-line teams. Workers are drowned in information; many object at the idea of attending more meetings. But the emphasis is on improving productivity and satisfying customers. Conflict and choice are played down. There is less close questioning of management decisions. To the extent top management consults with work teams, it bypasses governing councils.

Education has always played an important role in Mondragon, but its "traditionally evangelistic stance about spreading cooperativism" (p. 147) receives less emphasis today. In sum, Mondragon is losing much of its unique character as a social experiment and has become more like many typical "high commitment" capitalist organizations which provide their employees a considerable degree of individual autonomy, shop-floor participation, and job security. On the other hand, Mondragon's government remains democratic in form and to a considerable degree in practice and is by far the largest business about which this can be said. (An analogy can be drawn to unions, which also are democratic in form and to various degrees in practice.) 
Given my own interests I found this a fascinating book. It brought me up to date as to recent developments. I found myself, however, asking many questions. Values are important, I agree, but I would have liked some questionnaire data which made comparisons, not only over time but among the three coops studied most intensively and also between them and more typical capitalist firms. What differences in value still remain? Among Mondragon's 150 constituent coops are there some where the old values and behaviours still prevail? I wish I knew more about how governance actually works. To what extent are elections contested? What are the election issues? What role does KT (the quasi-union) play? I would have appreciated a few case studies as to how decisions are actually made. As Cheney's liberal quotations illustrate, clearly there are thoughtful individuals in high places who worry about recent trends. How many members share their concerns?

Cooperativism is a dream I share. What did Mondragon do wrong? With the benefit of hindsight, what might it have done differently? If Mondragon's experience was inevitable, what hope is there for developing democratic work systems anywhere? Cheney ends his book with a lengthy discussion of how market principles are becoming predominant, both in Mondragon and society generally. But he suggests few answers to the questions just raised. Neither can I.

George Strauss

University of California, Berkeley

\section{Mixed Methodology: Combining Qualitative and Quantitative Approaches by Abbas TASHakKori and Charles Teddlie, Thousand Oaks, Calif.: Sage Publications, 1998, 185 p., ISBN 0-7619-0070-5 (cloth: alk. paper) and ISBN 0-7619-007103 (pbk.: alk. paper).}

The field of Industrial Relations is a field of battle. The wars I refer to are not between unions and management, but among researchers, over research methodologies. Institutional economists battle those with econometric model approaches. In Sociology and Psychology qualitative case studies vie with survey methods and experimental designs.

Because I.R. is an interdisciplinary field, these disputes are expected. We are nurtured and trained in our disciplinary paradigms - to some of us, research IS regression! But because I.R. is also an applied field, these disputes prevent the field from achieving all it could. Why? The reason is simple. In a traditional academic discipline, problem selection and methods for exploring it are dictated by a paradigm (or one of several paradigms in the war zone that is Sociology). In contrast, applied fields involve real-world, immediate problems of concern to policy-makers or organi- zations, and in solving these problems the most useful results and clearest understanding are achieved when the problem itself drives the choice of methodology.

Alas, most of us are content to remain in the safety of our paradigms. We continue to do variations of regression, or case studies, or surveys, or experiments, because of the comfort and convenience of familiarity, and the suspicion that other methodologies simply do not do it right. In particular, those with quantitative skills do quantitative work, and those with qualitative approaches do qualitative projects. The quantitative/qualitative qualms typify the war - the war between the Qs.

To this battlefield I would like to send in a peace-keeper of a book. Tashakkori and Teddlie offer a compelling and coherent argument for employing a broader range of methodologies in our research. They present a reasoned, 